\title{
LOCATION OF THE PROANTHOCYANIDINS IN THE BARLEY GRAIN
}

\author{
by \\ STEN AASTRUP, HENRIK OUTTRUP and KENNETH ERDAL \\ Carlsberg Research Laboratory, Department of Brewing Chemistry \\ Gamle Carlsberg Vej 10, DK-2500 Copenhagen, Valby
}

Keywords: Anthocyanogens, proanthocyanidin-free barley, vanillin test, testa, nucellus.

\begin{abstract}
A vanillin $-\mathrm{HCl}$ staining has been used to locate the proanthocyanidins in mature barley grains. These flavanoids were found to be concentrated in the seed coat (testa) just outside the aleurone layer in the 7 varieties with yellow coloured grains investigated. The seed coats of 10 proanthocyanidin-free barley mutants belonging to 4 different gene loci did not stain with vanillin- $\mathrm{HCl}$.
\end{abstract}

\section{INTRODUCTION}

Proanthocyanidins in barley, to brewers known as anthocyanogens, have been the subject of intensive studies $(9,10,15,17)$ and their role in brewing as part of colloidal haze in beers is well documented $(4,16)$. The availability of proanthocyanidin-free barley mutants has given direct proof of this: From such barley mutants beer with an excellent haze stability has been produced $(1,20)$. No other beer characteristics, e.g. beer flavour $(5,6)$ was influenced by the use of proanthocyanidin-free barley.

In the barley grain the proanthocyanidins are believed to be located in the aleurone layer and pericarp (2, 11). REICHARD in 1904 (18) found that when half-cut barley grains were treated with ferrous sulphate a blue-black stain developed immediately under the husk. He regarded this reaction as due to a protein-tannin complex. MULLICK and BRINK (13) and JENDE-STRID (7) attempted to locate anthocyanins and proanthocyanidins in the husk (lemma + palea), pericarp, testa (spermoderm) and aleurone by peeling off successive layers with subsequent extraction of the separated peels.

In the present study the flavanoid compounds are rendered visible by staining half seeds of barley with a vanillin- $\mathrm{HCl}$ solution. This staining technique has been applied to barley grains with and without proanthocyanidins.

\section{MATERIALS AND METHODS}

\subsection{Plant material}

Seven commercial barley varieties, one proanthocyanidin-rich and ten proanthocyanidin-free mutants $(7,8,19)$ were analysed (Table I). All samples were obtained from Carlsberg Plant Breeding.

\subsection{Proanthocyanidin determination}

The content of proanthocyanidin in barley grains was determined as described earlier (20). 
Table I.

Proanthocyanidin content and reaction with vanillin$\mathrm{HCl}$ of barley varieties and ant-mutants.

\begin{tabular}{|c|c|c|}
\hline Variety/Mutant & $\begin{array}{l}\text { Proanthocyanidin } \\
\text { content } \mathrm{mg} / 100 \mathrm{~g}\end{array}$ & $\begin{array}{c}\text { Reaction with } \\
\text { vanillin- } \mathrm{HCl} \\
\text { in seed coat }\end{array}$ \\
\hline Triumph & 184 & + \\
\hline ant 13-152 & 0 & - \\
\hline ant $17-148$ & 0 & - \\
\hline ant $17-185$ & 0 & - \\
\hline Foma & 162 & + \\
\hline ant 13-13 & 0 & - \\
\hline Nordal & 215 & + \\
\hline ant $17-105$ & 0 & - \\
\hline ant $18-102$ & 0 & - \\
\hline Alf & 182 & + \\
\hline ant 18-111 & 0 & - \\
\hline ant $19-109$ & 0 & - \\
\hline Gula & 177 & + \\
\hline ant $18-164$ & 0 & - \\
\hline Ark Royal & 248 & + \\
\hline ant $13-172$ & 0 & - \\
\hline Bonus & 295 & + \\
\hline ant 3-5 & 315 & + \\
\hline
\end{tabular}

\subsection{Staining}

Seeds or abraded seeds were hand-cut in halves and placed for $1 / 2 \mathrm{~h}$ in a $1 \%$ vanillin- 6 $\mathrm{M}-\mathrm{HCl}$ solution which stains proanthocyanidins and catechins yielding an intense red colour. After staining the half seeds were washed in distilled water and stored at $-20^{\circ} \mathrm{C}$.

\subsection{Tissue preparation and microscopy}

Stained and unstained half seeds were inspected at low magnification. Thin sections (10 $\mu \mathrm{m}$ ) were then made on a Reichert Jung Frigocut 2700 Cryotone (Jung, W. Germany) and transferred to moist gelatine-coated slides before examination at higher magnification in a Reichert Univar microscope (Reichert, Austria). Photographs were taken on Kodak Ektachrome 400 films (Kodak, U. S. A. ).

\section{RESULTS}

After treatment with vanillin- $\mathrm{HCl}$ all the commercial varieties with a yellow coloured grain and normal proanthocyanidin content as well as the proanthocyanidin-rich mutant ant 3-5 showed a red stained seed coat (testa) (cf. 3), enveloping the aleurone and endosperm. None of the ten proanthocyanidin-free mutants representing mutations in four different gene loci showed staining of the seed coat (Table I).

The red stained seed coat (testa) comprising in the mature grain the compressed cell layers of the testa and nucellus is illustrated in Figure 1 a-c: a) shows a low magnification of a stained half seed in which the red coloured tissue between the husk and the endosperm is clearly seen. In b) showing a thin section at higher magnification a more exact location of the catechins and proanthocyanidins to the seed coat is possible. In c) the stained seed coat in a thin section of an abraded seed is shown at high magnification. It is seen to consist of several cell layers with adhering portions of the unstained pericarp on the outside. Figure $2(a-c)$ are comparable photographs after treating proanthocyanidin-free grains of mutant ant 13-13 with vanillin- $\mathrm{HCl}$. The seed coat remained unstained in the proanthocyanidin- and catechin-free mutant.

\section{DISCUSSION}

To the extent the vanillin- $\mathrm{HCl}$ reaction is specific for proanthocyanidins and catechins the present investigation indicates that these flavanoids are located in the seed coat (testa) of the mature grain. The specificity of the reaction is strongly supported by the observation that the seed coat of the mutants free of proanthocyanidins and catechins lack a positive reaction with the vanillin- $\mathrm{HCl}$ stain. Furthermore, tannins reacting with vanillin- $\mathrm{HCl}$ have been demonstrated in the testa of sorghum (12).

MuLLICK et al. (14) have analysed the flavanoid composition of the combined pericarp and aleurone tissues of the four colour types known among cultivated barley varieties: The yellow grains (called white) contained only proanthocyanidins and very little if any anthocyanins in these tissues. The black grains represented by 


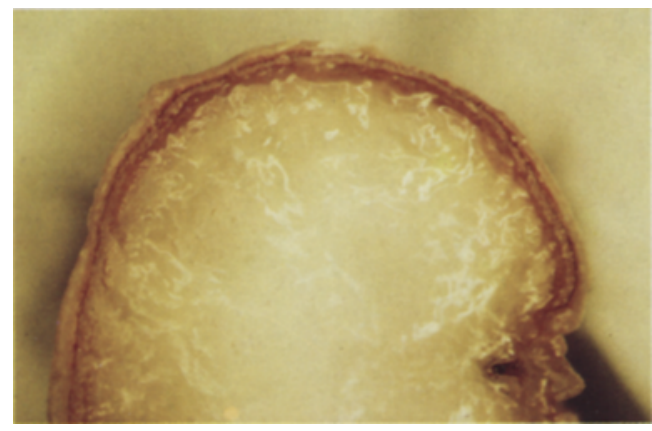

a

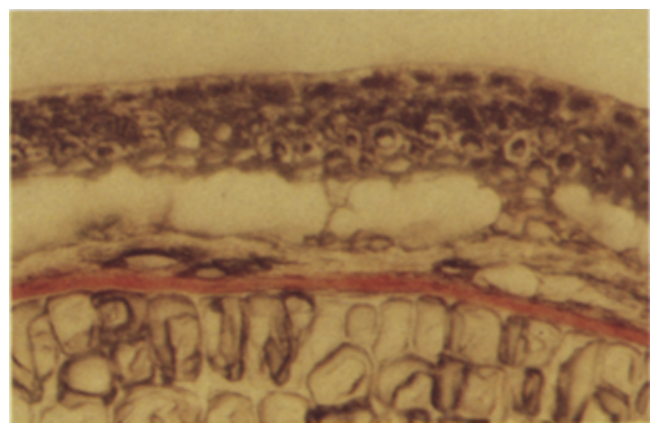

b

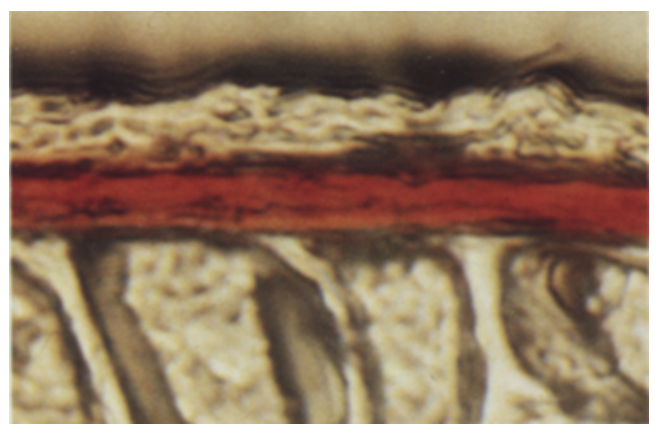

C

Figure 1. Barley grains with normal proanthocyanidin content stained with vanillin- $\mathrm{HCl}$ solution.

a) Hand-cut half seed of Nordal (20x).

b) Thin-section $(10 \mu \mathrm{m})$ of Triumph $(400 \mathrm{x})$.

c) Thin-section $(10 \mu \mathrm{m})$ of abraded Bonus $(1000 \mathrm{x})$.

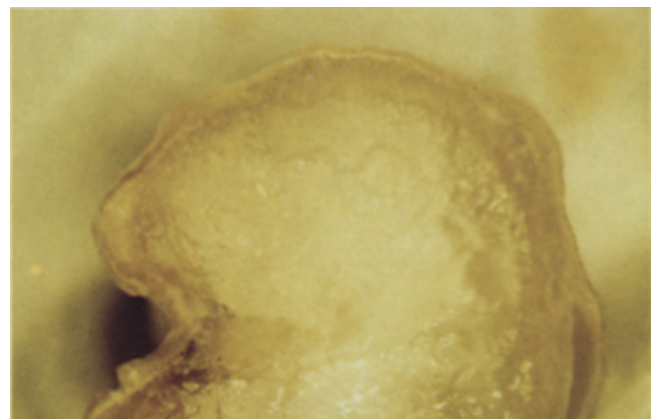

a

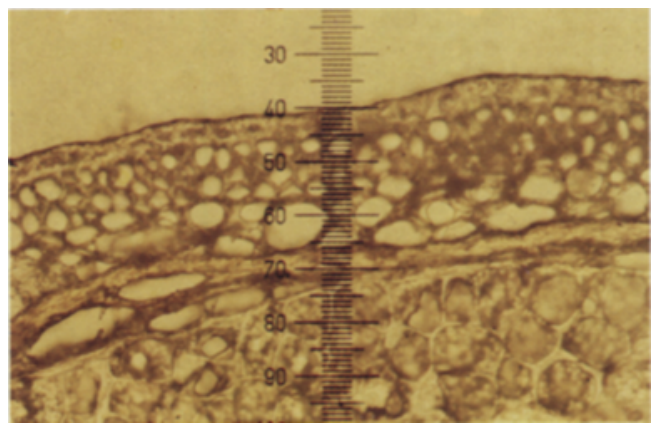

b

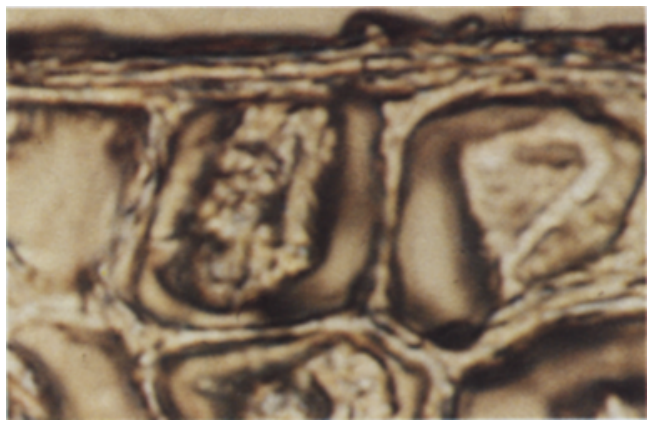

C

Figure 2. Proanthocyanidin-free barley grains stained with vanillin- $\mathrm{HCl}$ solution.

a) Hand-cut half seed of ant 13-13 (20x).

b) Thin-section $(10 \mu \mathrm{m})$ of ant 13-13 (400x). One graduation mark: $2,5 \mu \mathrm{m}$.

c) Thin-section $(10 \mu \mathrm{m})$ of abraded ant 13-13(1000x). 
Lion and Gatami contained proanthocyanidins and sometimes also anthocyanins. The black colour is not attributable to anthocyanidins. The blue colour in grains (Kwan, Trebi, Montcalm) is due to delphinidin and cyanidin whereas the purple grains (Gopal, Black Hulless) contain delphinidin, cyanidin and pelargonidin. These specific distributions in the content of proanthocyanidins and the anthocyanins in the grains of the four colour types have been confirmed in a recent study (7). MULLICK and BRINK (13) located the anthocyanins of the purple variety Black Hulless to a layer called spermoderm which is adjacent to the aleurone layer and thus must correspond to the seed coat (testa). It appears, however, very thick in this variety. JENDE-STRID (7) soaked the grains in water at 0 ${ }^{\circ} \mathrm{C}$ for 4 days and then peeled three layers designated as (1) palea + lemma, (2) pericarp + testa and (3) aleurone with some adhering endosperm. She determined by extraction with $1 \%$ $\mathrm{HCl}$ in methanol the amount of anthocyanin and after treatment with conc. $\mathrm{HCl}$ the amount of proanthocyanidin in the three layers. In the yellow coloured varieties and 37 ant-mutants blocked in the synthesis of anthocyanins most of the proanthocyanidins were present in the third layer $i$. e. that containing the aleurone cells but also the other two layers contained some proanthocyanidins. Apparently a clean separation of the different layers cannot be achieved by the peeling procedure and in the light of the present histochemical analysis most of the testa tissue in the yellow coloured varieties must have remained with the peels designated as aleurone in the earlier work (7). In the black varieties free of anthocyanins about equal amounts of proanthocyanidins were found in all three layers, while in the blue varieties proanthocyanidins were equally distributed among all three peels and the anthocyanins concentrated in the layer containing the aleurone cells. In the purple naked varieties both anthocyanins and proanthocyanidins were distributed among the two peeled layers which could be obtained from these strains. It will be of interest to use the present vanillin- $\mathrm{HCl}$ procedure to analyse these different pigmented groups of barley grains.

The seed coat originates from at least three cell layers in the developing grain (3). Adjacent to the aleurone cells the nucellus cells with a thick epidermal wall and a cuticula are found. Next are two cell layers of the testa bounded by a cuticula bordering the cross cells of the pericarp. The technique presented here enables a study of the intercellular distribution of anthocyanins and proanthocyanidins in these three cell layers of the developing grain.

\section{ACKNOWLEDGEMENTS}

The authors wish to express their appreciation to Professor D. von WeTtSTEIN for help in preparation of the manuscript. The excellent technical assistance of Ms. Ella MEILING is gratefully acknowledged.

\section{REFERENCES}

1. Ahrenst-Larsen. B. \& K. Erdal: Anthocyanogen-free barley - a key to natural prevention of beer haze. Europ. Brewery Conv. Congr. Proc. Berlin 1979, 63)-644 (1979)

2. Briggs, D. E. , J. S. Hough, R. Stevens \& T. W. YOUNG: Malting and brewing science, vol. 1, Sec. ed. , Chapman and Hall, London and New York (1981)

3. Cameron-Mills, V. \& D. von Wettstein: Protein body formation in the developing barley endosperm. Carlsberg Res. Commun. 45, 577-594 (1980)

4. Curtis. N. S.: Non-biological beer hazes. In: Modern Brewing Technology. W. P. K. Findlay, ed. , Macmillan Press, London, pp. 254-291 (1971)

5. Erdal. K. B. Ahrenst-Larsen \& B. JendeSTRID: Use of proanthocyanidin-free barley in beer brewing. In: Cereals for food and beverages. G. E. Inglett \& L. Munck, eds. , Academic Press, New York, pp. 365-379 (1980)

6. Erdal, K. H. Outtrup \& B. Ahrenst-Larsen: The role of proanthocyanidins in beer flavour and flavour stability. Europ. Brewery Conv. Congr. Proc. London 1983, 557-564 (1983)

7. Jende-Strid, B: Mutations affecting flavonoid synthesis in barley. Carlsberg Res. Commun. 43, 265-273 (1978)

8. JENDE-STRID, B.: Coordinators report: Anthocyanin genes. Barley Genetics Newsletter 14 (1984) (in press)

9. Jende-Strid, B. \& B. Lindaerg Møller: Analysis of proanthocyanidins in wild-type and mutant barley (Hordeum vulgare L. ). Carlsberg Res. Commun. 46, 53-64 (1981) 
10. JeRumanis, J.: Separation et identification de flavonoides par chromatographie liquide a haute performance (HPLC). Europ. Brewery Conv. Congr. Proc. Berlin 1979, 309-319 (1979)

11. MOLL. M: Analysis and composition of barley and malt. In: Brewing Science, vol. 1.J. R. A. Pollock, ed. , Academic Press, London, pp. 1-143 (1979)

12. Morrall, P. , N. v. D. W. Liebenberg \& C. W. GLENNIE: Tannin development and location in bird-resistent sorghum grain. Scanning electron microscopy, 3, 571-576 (1981)

13. MUlLICK. D. B. \& V. C. BRINK: Localization of Anthocyanidins by Peeling the Investments of the Barley Caryopsis. Crop Science, 6, 204-206 (1966)

14. MUlLICK, D. B. , D. G. FARIS, V. C. BRINK \& R. M. ACHESON: Anthocyanins and anthocyanidins of the barley pericarp and aleurone tissues. Can. J. Plant. Sci. 38, 445-456 (1958)

15. Outtrup, $H$.: Structure of prodelphinidins in barley. Europ. Brewery Conv. Congr. Proc. Copenhagen 1981, 323-333 (1981)
16. Outtrup, H. \& K. ERdal: Haze forming potential of proanthocyanidins. Europ. Brewery Conv. Congr. Proc. London 1983, 307-314 (1983)

17. Outtrup. H. \& K. Schaumburg: Structural elucidation of some proanthocyanidins in barley by 'H $270 \mathrm{MHz}$ NMR spectroscopy. Carlsberg Res. Commun. 46, 43-52 (1981)

18. Reichard, A.: Zur Kenntnis der Gerbstoffgehaltes der Gerste, des Maltzes und ungehopfter Würzen. Zeitschrift für das gesamte Brauwesen, 27, 229-235, 253-258, 271-275 (1904)

19. Wettstein, D. von. B. Jende-Strid. B. AhRENST-LARSEN \& K. ERDal: Proanthocyanidinfree barley prevents the formation of beer haze. MBAA Technical Quarterly 17, 16-23 (1980)

20. WetTStein, D. von, B. Jende-Strid, B. AHRENST-Larsen \& J. A. SøREnSEN: Biochemical mutant in barley renders chemical stabilization of beer superfluous. Carlsberg Res. Commun. 42 , 341-351 (1977) 